\title{
Resultados del manejo multidisciplinario del labio y paladar fisurado unilateral
}

\author{
Results of the multidisciplinary handling of the lip and of paladar fisurado unilateral
}

El tratamiento del labio y paladar hendido ha evolucionado a lo largo de los siglos, haciéndose cada vez más complejo y buscando cada vez unos objetivos más elevados, con perfeccionamiento de las técnicas quirúrgicas y creación de equipos multidisciplinares que traten todas las facetas de este tipo de patología desde el momento del nacimiento hasta la edad adulta.

Los distintos especialistas implicados han de estar en conexión desde el momento del nacimiento, yuxtaponiendo sus actuaciones en el tiempo, pudiendo llegar a provocar modificaciones en el protocolo de actuación los resultados obtenidos por cada uno de los profesionales del equipo.

Así, ya desde el momento del nacimiento podrá ser necesaria la colaboración del ortodoncista a la hora de realizar un tratamiento ortodóntico prequirúrgico en busca del alineamiento de las arcadas alveolares para facilitar el cierre de la parte anterior de la fisura y la reconstrucción del suelo nasal. El momento del cierre del labio y del paladar, así como la técnica quirúrgica empleada, se ha visto que también son determinantes a la hora de poder obtener unos resultados más positivos, tanto estéticos como funcionales.

La colaboración del logopeda se inicia en la primera infancia, para utilizar adecuadamente los mecanismos de compensación fonatorios. Este tratamiento se mantendrá hasta la adolescencia, ya que la atrofia del tejido adenoideo en la pubertad hará necesario una revisión de la fonación. El grado de incompetencia velofaríngea podrá sentar la indicación de la necesidad de realizar técnicas quirúrgicas complementarias sobre el paladar blando, o el cierre de fístulas oronasales. El ortodoncista seguirá siendo un colaborador fundamental durante todo este tiempo, para controlar la aparición de compresiones maxilares por inclinación del segmento maxilar fisurado, tanto antes como después de la alveoloplastia secundaria y aún con posterioridad, para mantener una adecuada coordinación de las arcadas y realizar un posible tratamiento ortodóntico preortognático por hipoplasia o retrusión maxilar.

El presente artículo pretende dar a conocer los resultados obtenidos gracias al tratamiento multidisciplinar de pacientes con fisura labiopalatina, pero no alcanza su objetivo, ya que se limita a presentar los resultados estéticos de las reparaciones de la fisura, de forma farragosa y con contradicciones en los datos estadísticos.

En el apartado de Material y Método hace referencia a una valoración ortodóncica mediante estudios cefalométricos, con empleo de parámetros únicamente de posicionamiento del maxilar superior e inferior, sin tener en cuenta las posibles alteraciones secundarias a la compresión palatina, tan frecuente en estos pacientes. Pero además no hace referencia a cuáles fueron los hallazgos, cuál
The processing of the lip and paladar cleaved has evolved throughout the centuries, becoming more and more complex and looking for every time higher objectives, with improvement of the surgical techniques and creation of equipment you will multidiscipline that they deal with all the facets this type of pathology from the moment of the birth to the adult age.

The different implied specialists have to be in connection from the moment of the birth, juxtaposing their performances in the time, being able to get to cause modifications in the performance protocol the results obtained by each one of the professionals of the equipment.

Thus, already from the moment of the birth the collaboration of the ortodoncista at the time of making a presurgical ortodóntico processing in search of the alignment of the alveolar arches could be necessary to facilitate the closing of the forcebody of the fissure and the reconstruction of the nasal ground. The moment of the closing of the lip and paladar, as well as the used surgical technique, it has been seen that also they are determining at the time of being able to obtain more positive results, aesthetic as as much functional.

The collaboration of logopeda begins in the first childhood, to use the fonatorios mechanisms of compensation suitably. This processing will stay until the adolescence, since the atrophy of the adenoid weave in the puberty will make an overhaul necessary of the phonation. The degree of velofaringea incompetencia will be able to seat the indication of the necessity to make complementary surgical techniques on soft paladar o el cierre de fístulas oronasales. The ortodoncista will continue throughout being a fundamental collaborator this time, in order to control the appearance of compressions maxilares by inclination of the segment to maxilar fisurado, as much before as after alveoloplastia secondary and still later, in order to maintain a suitable coordination of the arches and to make a possible preortognático ortodóntico processing by hipoplasia or retrusión to maxilar.

The present article tries to present the results obtained thanks to the processing to multidiscipline of patients with labiopalatina fissure, but it does not reach its objective, since it is limited to present/display the aesthetic results of the repairs of the fissure, farragosa form and with contradictions in the statistical data.

In the section of Material and Method it makes reference to a ortodóncica valuation by means of cefalométricos studies with use of parameters solely of positioning of superi- 
fue la planificación ni cuáles los resultados. Otro tanto se produce en cuanto a la valoración del tratamiento logopédico.

El artículo podría entenderse como una exposición de la experiencia acumulada por sus autores, pero sin poder obtener conclusiones debido a la diversidad de técnicas empleadas, pero desde luego no se puede entender como desarrollo del título elegido.

Almudena Alonso Ovies Servicio de Cirugía Oral y Maxilofacial Hospital Clínico San Carlos, Madrid, España or and inferior maxilar, without considering the possible secondary alterations to the palatal, so frequent compression in these patients.

But in addition it does not make reference to which were the findings, which was the planning nor which the results. The same takes place as far as the valuation of the logopédico processing.

The article could be understood like a exhibition of the accumulated experience by its authors, but without being able to obtain conclusions due to the diversity of used techniques, but of course it is not possible to be understood like development of the chosen title. 